\title{
Correction to: Philanthropy in China: Institutional and Social Factors
}

S. $\mathrm{Ye}^{1}$

Published online: 29 August 2019

(C) International Society for Third-Sector Research 2019

\section{Correction to: \\ Voluntas (2017) 28:1785-1811 \\ https://doi.org/10.1007/s11266-017-9864-y; \\ Voluntas (2018) 29:1176-1189 \\ https://doi.org/10.1007/s11266-018-0044-5}

The present special issue (Philanthropy in China: Institutional and Social Factors) should also include the previously published papers linked below: https://link.springer.com/article/10.1007/s11266-0180044-5.

https://link.springer.com/article/10.1007/s11266-0179864-y.

Publisher's Note Springer Nature remains neutral with regard to jurisdictional claims in published maps and institutional affiliations.

The original articles can be found online at https://

doi.org/10.1007/s11266-017-9864-y; https://doi.org/10.1007/s11266018-0044-5.

\footnotetext{
S. Ye

shye@swk.cuhk.edu.hk

1 Shatin, Hong Kong
} 